\title{
Isparta İli ve Çevresinde Siğırcılık İsletmelerinde Bovine Viral Diyare Virus (BVDV) Enfeksiyonunun Serolojik Olarak Araştırılması
}

\author{
Serological Investigation of Bovine Viral Diarrhea Virus (BVDV) Infection in Dairy Cattle Herds in Isparta Province

\section{İlker BİLGİLİ ${ }^{*}(\mathbb{D})$, Nuri MAMAK²} \\ ${ }^{1}$ Uluborlu Tarım ve Orman İlçe Müdürlüğ̈̈, Isparta, Türkiye \\ ${ }^{2}$ Burdur Mehmet Akif Ersoy Universitesi, Veteriner Fakültesi, İç Hastalıkları Anabilim Dalı, Burdur, Türkiye
}

\begin{abstract}
Öz: Bu çalışma, Isparta İli ve çevresinde sığırcılık işletmelerinde Bovine Viral Diyare Virus (BVDV) enfeksiyonunun seroprevalansının araştırılması amacıyla yapıldı. Çalışmada, 24 işletmeden toplanan 6 ay -12 yaşlı 460 adet dişi sığır kan serumu kullanıldı. Hayvanlara ait kan örnekleri V. Jugularis'ten $10 \mathrm{ml}$ 'lik steril vakumlu tüplere alındı. Tüpler 2000 devirde $10 \mathrm{dk}$. santrifüj edildi. Serumlar test yapilncaya kadar $-25^{\circ} \mathrm{C}^{\prime}$ de derin dondurucuda saklandi. Serumlarda BVDV'una karșı antikor (Ab) varllğını belirlemek için BVDV (Ab)-ELISA, BVDV antijen (Ag) varlığını belirlemek amaciyla BVDV (Ag)-ELISA test kitleri kullanildı. Alınan kan örneklerinden 346's1 (\%75.22) seropozitif, 114'ü (\%24.78) seronegatif ve 5 tanesi de (\%1.09) persiste enfekte (PI) olarak belirlendi. Holştayn \%76.22, Simental \% 72.22 , Montofon ırkında \%46.15 oranında seropozitiflik tespit edildi. Irklara göre ve yaş grupları arasındaki seropozitifliğin istatistiksel açıdan anlamlı olduğu belirlendi $(\mathrm{p}<0.05)$. Ayrıca yaş arttıkça seronegatifliğin azaldığı saptandı. Bu çalışma, Isparta İli ve çevresinde BVD enfeksiyonunun seroprevalansını tespiti amacıyla yapılan ilk çalışma özelliği taşımaktadır. Sonuç olarak; BVDV enfeksiyonu seropozitiflik ve PI oranı değerlendirildiğginde, enfeksiyonun Isparta İli ve çevresinde yaygın olduğu görülmektedir. Bu nedenle hastalığa karşı gerekli kontrol ve koruma çalışmalarının yapılması bölge ve ülke ekonomisi için önem arz etmektedir.
\end{abstract}

Anahtar Kelimeler: BVDV, ELISA, Isparta, seroloji, sı̆̆ır.

\begin{abstract}
The aim of this work is to investigate the seroprevalance of Bovine Viral Diarrhoe Virus (BVDV) infection in the cattle farm in Isparta and its provinces. In the study 460 female bovine serum aged between 6 months-12 years situated in 24 farm were used. Blood samples of the animals from V. jugularis were collected into $10 \mathrm{ml}$ sterile vacuum tubes. Tubes were centrifuged for $10 \mathrm{~min}$ at $2000 \mathrm{rpm}$. Serum samples were stored in a freezer at $-25{ }^{\circ} \mathrm{C}$ until they used. To determine the presence of BVDV antibodies (Ab) in the serum BVDV (Ab)-ELISA test kits and to determine the presence of BVDV antigen (Ag) in the serum BVDV (Ag)-ELISA test kits were used. Out of 460 obtained blood samples $346(74.35 \%)$ were seropositive, $114(23.91 \%)$ were seronegative and $5(1.09 \%)$ were determined as persistent infected (PI). Seropositivity rate by breeds were determined as $76.22 \%$ in Holstein, $72.22 \%$ in Simmental and $46.15 \%$ in Montofon breed. Seropositivity between breeds and age groups were determined statistically significant $(\mathrm{p}<0.05)$. Furthermore, it was detected that as age increases seronegativity decreased. This study is the first study conducted in order to determine the seroprevalence of BVD infection in Isparta and its provinces. As a result; when the seropositivity and PI rates of BVDV infection was considered the infection is widespread in Isparta and its provinces. Therefore, it is important to design control and protection precautions against disease to improve regional and national economy.
\end{abstract}

Keywords: BVDV, ELISA, Isparta, serology, cattle.

${ }^{*}$ Corresponding author : İlker BİLGİLI

Geliş tarihi / Received : 01.11.2019

e-mail : dr.ilkerbilgili@gmail.com

Kabul tarihi / Accepted: 12.12.2019

\section{Giriş}

Bovine Viral Diarrhea Virüs (BVDV) enfeksiyonu dünya genelinde yaygin bir patojen olup, sığır yetiştiriciliğinde ciddi ekonomik kayıplara neden olmaktadır (Ridpath ve ark., 2010; Xue ve ark., 2009). Virüs, çeşitli virülense sahip olup, sığırlarda klinik ve subklinik seyir gösterir. Enfeksiyona 
maruz kalan hayvanlarda solunum, sindirim ve genital organlarda ciddi lezyonlar, immünsüpresyon, şiddetli ishal, mukozal hastalık (MD), gebe hayvanlarda abort, yeni doğanlarda konjenital defektler, malformasyonlar ve neonatal mortalite ile seyretmektedir (Greiser-Wilke ve ark., 2003; Rodning ve ark., 2010). Bir sürüde erken embriyonik ölümler, mumifikasyonlar, konjenital malformasyonlar, yavru atmalar, döl tutma problemleri, solunum sistemi enfeksiyonlar1, ishal, ateş, lökopeni ve trombositopeni gibi bulguların yer alması hastalıktan şüphe ettirir (Decaro ve ark., 2012). Hastalıkta, embriyonik ölüm, fötal mumifikasyon, gebelik oranında düşme, abort, erken doğum, ölü doğum, konjenital defekt, c1lız buzağ1 doğumu ve Persiste enfekte (PI) hayvan doğumu gerçekleşmektedir (Grooms, 2004; McGowan ve ark., 1993; Robert ve ark., 2004). Etkilenen buzağılarda ataksi, geniş tabanlı duruş, sendeleyerek yürüme, kalkmaya çalışırken geriye düşme, katarakt, mikroftalmi, optik nevritis, retinal dejenerasyon, timus hipoplazisi, hipotrikoz, alopesi, sırtlan hastalığ1, bukleli k1l örtüsü, brachygnathia, gelişme geriliği, kemik gelişiminde dengesizlik şekillenmektedir (Radositist ve ark., 2006). BVDV kontrol programı olmayan ülkelerde, yaklaşık \%1-2 oranında Persiste infekte (PI) hastalar ile karşılaşılır (Duong ve ark., 2008). Türkiye'de BVDV hastalığının prevalans1 \%46-86 oranında, persiste enfekte hayvan varlığ ise \%0.07-4.9 arasında değişmektedir (Avcı ve Yavru, 2013). Bu çalışmada, Isparta İli ve çevresinde sığırcıllk işletmelerinde Bovine Viral Diyare Virus (BVDV) enfeksiyonunun seroprevalansinın araşturılması amaçlandı.

\section{Gereç ve Yöntem}

\section{Kan Örnekleri}

Çalışma için Süleyman Demirel Üniversitesi Hayvan Deneyleri Yerel Etik Kurulu'nun 06.03.2014 tarih ve 01 sayll karar1 ile etik kurul izni alındı. Çalışma, Isparta ili ve çevresinde 24 adet farklı işletmeden 6 ay ile 12 yaş arasında BVDV aşısı uygulanmamış sağlıklı görünüme sahip 460 tane dişi sığır ile yürütüldü.
Vena jugularis'ten $10 \mathrm{ml}$ kan uygun şekilde alındı. Kanlar 2000 devirde 10 dakika santrifüj edilerek çıkarılan serumlar $-25^{\circ} \mathrm{C}$ 'de çalışma yapılıncaya kadar saklandi.

\section{ELISA Testi}

BVDV (Ab)-ELISA (IDEXX BVDV-Total Ab, Switzerland) ve BVDV (Ag)-ELISA (IDEXX BVDV Ag/Serum Plus, Switzerland) kitleri kullanıldı. Kan serumları ve kitte kullanilan kimyasallar oda sicaklığına gelecek şekilde ortalama 1 saatlik zaman diliminde oda sıcaklığında bekletildi.

\section{BVDV (Ab) Testi}

Serumlar BVDV 'ye karşı gelişen antikor varlığ yönünden indirekt ELISA (BVDV (Ab)-ELISA (IDEXX BVDV-Total Ab, Switzerland) ile incelendi.

\section{BVDV (Ag) Testi}

Elde edilen serum örnekleri BVDV antijen varllğ̆1 yönünden direkt ELISA (IDEXX, BVDV Ag test, Switzerland) ile incelendi.

\section{Ístatistiksel Analiz}

Bu çalışmada, ırklar ve yaş grupları arasında ChiSquare $\left(\mathrm{X}^{2}\right)$ testi (Minitab 16 statistical software, USA) ve korrelasyon testi (Minitab 16 statistical software, USA) ile istatistiksel analizleri yapildı. $\mathrm{p}<0.05$ 'ten küçük olan değerler istatistiksel olarak önemli kabul edildi.

\section{Bulgular}

\section{ELISA Sonuçları}

ELISA test kiti kullanılarak 460 adet sığırda yapılan çalışmada 342 adet seropozitif (\%74.35), 110 adet seronegatif (\%23.91), 8 adet (\%1.74) şüpheli bulundu. Şüpheli hayvanlardan 45 gün sonra tekrar kan alındı ve test yapıldı. Şüpheli olan 8 hayvanın 4 tanesi seropozitif, 4 tanesi seronegatif olarak tespit edildi. Kan örneklerinin, serolojik olarak sayısal ve oransal dağılımları Tablo 1 ve Tablo 2'de sunulmuştur. 
İlçeler bazında serolojik bulgular değerlendirildiğinde; Atabey ilçesinden 40 adet kan alındi, $36(\% 90)$ tanesi seropozitif, $4(\% 10)$ tanesi seronegatif olarak bulundu. Eğirdir ilçesinden 37 adet kan alındı, 32 (\%86.49) tanesi seropozitif, 5 (\%13.51) tanesi seronegatif bulundu. Gönen ilçesinden 48 adet kan alındı, $42(\% 87.50)$ tanesi seropozitif, $6(\% 12.50)$ tanesi seronegatif bulundu. Keçiborlu ilçesinden 49 adet kan alındı, 42 $(\% 85.71)$ tanesi seropozitif, 7 (\%14.29) tanesi seronegatif tespit edildi. Senirkent ilçesinde 63 adet kan alındı 52 (\%82.54) tane seropozitif,
$11(\% 17.46)$ tane seronegatif belirlendi. Şarkikaraağaç ilçesinden 103 adet kan alındı 77 (\%74.76) tane seropozitif, $26(\% 25.24)$ seronegatif bulundu. Yalvaç ilçesinden 111 adet kan alındı 57 $(\% 51.35)$ tanesi seropozitif, $54(\% 48.65)$ tanesi seronegatif, Isparta ili merkezinde ise 9 tane kan alındı 8 (\%88.89) tanesi seropozitif, 1 (\%11.11) tane seronegatif tespit edildi. Oransal dağllimlar Tablo 2' de sunulmuştur. (Tablo 2)

Tablo 1. Kan serumlarının serolojik olarak sayısal ve oransal dağılımı.

\begin{tabular}{lcc}
\hline Serolojik Sonuç & Hayvan Sayıs & Oran (\%) \\
\hline Seropozitif & 346 & 75.22 \\
Seronegatif & 114 & 24.78 \\
\hline Toplam & $\mathbf{4 6 0}$ & $\mathbf{1 0 0}$ \\
\hline
\end{tabular}

Tablo 2. Isparta ili ve çevresinde kan örneği alınan yerlerin örnek sayıları, serolojik olarak sayıları ve oransal dağılımı.

\begin{tabular}{lccccc}
\hline \multirow{2}{*}{$\begin{array}{c}\text { Örnek Alınan } \\
\text { Yerler }\end{array}$} & \multicolumn{2}{c}{ Seropozitif } & \multicolumn{2}{c}{ Seronegatif } & $\begin{array}{c}\text { Toplam } \\
\text { Örnek } \\
\text { Sayıs1 }\end{array}$ \\
\cline { 2 - 5 } & Hayvan Sayısı & \% Değer & Hayvan Sayıs1 & \% Değer & \\
\hline Merkez & 8 & 88.89 & 1 & 11.11 & 9 \\
Atabey & 36 & 90 & 4 & 10 & 40 \\
Eğirdir & 32 & 86.49 & 5 & 13.51 & 37 \\
Gönen & 42 & 87.50 & 6 & 12.50 & 48 \\
Keçiborlu & 42 & 85.71 & 7 & 14.29 & 49 \\
Senirkent & 52 & 82.54 & 11 & 17.46 & 63 \\
Şarkikaraağaç & 77 & 74.76 & 26 & 25.24 & 103 \\
Yalvaç & 57 & 51.35 & 54 & 48.65 & 111 \\
\hline Toplam & $\mathbf{3 4 6}$ & \multicolumn{5}{|c}{} & $\mathbf{4 6 0}$ \\
\hline
\end{tabular}

Serolojik bulguların irklara göre dağılımı incelendiğinde; holştayn 1rkı sığırlardan 429 adet numune alınmıs olup $327 \quad(\% 76.22)$ tanesi seropozitif, $102(\% 23.78)$ seronegatif olarak tespit edildi. Simental $1 \mathrm{rk} 1$ sığılardan 18 adet kan numunesi alındı $13(\% 72.22)$ tanesi seropozitif, 5 $(\% 27.78)$ tanesi seronegatif bulundu. Montafon 1rkından 13 tane kan numunesi alındı $6(\% 46.15)$ tanesi seropozitif, 7 (\%53.85) tanesi seronegatif olarak belirlendi. Seropozitif ve seronegatif hayvanların ırklara göre sayısal ve oransal dağılımı tablo 3'te sunulmuştur. (Tablo 3)

Serolojik bulguların, yaş aralığına göre dağılımında 6 ay-3 yaş grubu arasında 146 adet hayvandan 74 (\%50.68) tanesi seropozitif, $72(\% 49.32)$ tanesi 
seronegatif, 3-6 yaş grubu arasında 207 hayvandan $170(\%$ 82.13) tanesi seropozitif, 37 (\%17.87) tanesi seronegatif; 6 yaş ve üzerindeki grup arasinda ise 107 hayvandan $102(\% 95.33)$ tanesi seropozitif, 5 (\%4.67) tanesi seronegatif olarak belirlendi. Seropozitif ve seronegatif hayvanların yaş grupları arasında sayısal ve oransal dağılımı Tablo 4'te sunulmuştur. (Tablo 4)

Çalışmada, Eğirdir ilçesinde 1 tane, Gönen ilçesinde 1 tane, merkezde 1 tane ve Senirkent ilçesinde bir işletmede 2 tane olmak üzere Isparta ili ve çevresinde 460 adet dişi sığırdan 5 (\%1.09) tanesi antijen pozitif bulundu. 45 gün sonra antijen pozitif olan hayvanlardan ikinci kez kan numunesi alınarak antijen arandi. 5 hayvanda yine antijenin pozitif olduğu tespit edildi ve bunlar persiste enfekte hayvan olarak değerlendirildi. Antijen pozitif olan hayvanların Isparta İli ve çevresine göre oransal dağıllımı Tablo 5'te sunulmuştur. (Tablo 5)

Tablo 3. Seropozitif ve seronegatif hayvanların ırklara göre sayısal ve oransal dağıllımı.

\begin{tabular}{lcccc}
\hline \multirow{2}{*}{ Irk } & \multicolumn{2}{c}{ Seropozitif } & Seronegatif \\
\cline { 2 - 5 } & Hayvan Sayıs1 & \% Değer & Hayvan Say1s1 & \% Değer \\
\hline Holştayn & 327 & 76.22 & 102 & 23.78 \\
Simental & 13 & 72.22 & 5 & 22.78 \\
Montafon & 6 & 46.15 & 7 & 53.85 \\
\hline Toplam Say1 & $\mathbf{3 4 6}$ & $\mathbf{1 1 4}$ & \\
\hline
\end{tabular}

Tablo 4. Seropozitif ve seronegatif hayvanların yaş grupları arasında sayısal ve oransal dağılımı.

\begin{tabular}{|c|c|c|c|c|}
\hline \multirow{2}{*}{ Yaş } & \multirow{2}{*}{$\begin{array}{c}\text { Seropozitif } \\
\text { Hayvan Sayıs1 }\end{array}$} & \multicolumn{3}{|c|}{ Seronegatif } \\
\hline & & \% Değer & Hayvan Sayıs1 & \% Değer \\
\hline 6 ay-3 yaş & 74 & 50.68 & 72 & 49.32 \\
\hline $3-6$ yaş & 170 & 82.13 & 37 & 17.87 \\
\hline 6 yaş ve Üzeri & 102 & 95.33 & 5 & 4.67 \\
\hline Toplam Say1 & 346 & & 114 & \\
\hline
\end{tabular}

Tablo 5. Antijen pozitif olan hayvanların Isparta İli ve çevresine sayısal ve oransal dağılımı.

\begin{tabular}{lccc}
\hline $\begin{array}{l}\text { Antijen Pozitif } \\
\text { Olan Yerler }\end{array}$ & $\begin{array}{c}\text { Antijen Pozitif } \\
\text { Hayvan Sayıs }\end{array}$ & Hayvan sayısı & $\begin{array}{c}\text { Oran } \\
\mathbf{( \% )}\end{array}$ \\
\hline Merkez & 1 & 9 & 11.11 \\
Atabey & - & 40 & - \\
Eğirdir & 1 & 37 & 2.70 \\
Gönen & 1 & 48 & 2.08 \\
Keçiborlu & - & 49 & - \\
Senirkent & 2 & 63 & 3.17 \\
Şarkikaraağaç & - & 103 & - \\
Yalvaç & - & 111 & - \\
\hline Toplam & $\mathbf{5}$ & 460 & $\mathbf{1 , 0 9}$ \\
\hline
\end{tabular}




\section{Ístatistiksel Değerlendirme}

Laboratuvar çalışmaları sonucunda elde edilen veriler ışığında yaş gruplanı ve ırklar arasında istatistiksel açıdan farkın olup olmadığı Chi-Square $\left(X^{2}\right)$ Test'i kullanilarak belirlendi. Tablo 6 ve Tablo 7'de sunulmuştur. (Tablo 6 ve 7)

Tablo 6'da görüldüğü gibi yaş grupları arasında $(p<0.05)$ istatiksel önem belirlendi. Ayrıca, yaş ile seropozitif ve seronegatiflik arasındaki korrelasyon testine göre yaş arttıkça seronegatifliğin azaldığ saptand.

Holştayn, Simental, Montafon irklar arasında da istatiksel önem belirlendi $(\mathrm{p}<0.05)$. Tablo 7 'de yapılan harflendirmeye göre değerlendirme yapıldığında, farklı harfler taşıyan gruplar arasında fark önemlidir.

Tablo 6. Yaş grupları arasında $\mathrm{X}^{2}$ testi istatistik tablosu.

\begin{tabular}{lccccc}
\hline Yaş & $\mathbf{n}$ & Seropozitif $(\mathbf{n})$ & Seronegatif $(\mathbf{n})$ & $\mathbf{\%}$ & $\boldsymbol{P}$ değeri \\
\hline 6 ay- 3 yaş & 146 & 74 & 72 & 50.68 & $*$ \\
3 - 6 yaş & 207 & 170 & 37 & 82.13 & $*$ \\
6 yaş ve üzeri & 107 & 102 & 5 & 95.33 & $*$ \\
\hline *P $<0.05$ & & & &
\end{tabular}

$* \mathrm{P}<0.05$

Tablo 7. Irklar arasında arasında $\mathrm{X}^{2}$ testi istatistik tablosu.

\begin{tabular}{lccccc}
\hline Irk & $\mathbf{n}$ & Seropozitif (n) & Seronegatif (n) & $\mathbf{\%}$ & Harflendirme \\
\hline Holştayn & 429 & 327 & 102 & 76.22 & $\mathrm{a}$ \\
Simental & 18 & 13 & 5 & 72.22 & $\mathrm{ab}$ \\
Montafon & 13 & 6 & 7 & 46.15 & $\mathrm{~b}$ \\
\hline
\end{tabular}

Chi-Square $=6.211 \mathrm{p}=0.045$

\section{Tartışma}

$\mathrm{Bu}$ çalışmada, hayvan sahiplerinden alınan anamnezlerde ölü doğumlar, gelişme geriliği, kongenital defekt, cıllz buzağı doğumu, değişken morbiditeli pnömo-enterit, döl tutma problemlerinde artşs olduğu bilgisine ulaşıldı. Bu klinik bulgular; birçok viral, bakteriyel hastalıkların yanı sira beslenme yetersizlikleri gibi nedenlerden de kaynaklanabilir. Fakat bu çalışmada, BVDV enfeksiyonu seroprevalansinin $\% 75.22$ ve PI oranının \%1.09 olarak tespiti, bu klinik bulguların BVDV enfeksiyonundan kaynaklandığının önemli bir göstergesidir.
BVDV' nin prevalansı, dünyanın farklı bölgelerinde değişiklik göstermekte ve \%12-89 arasında olduğu bildirilmektedir (Kuta ve ark., 2013).

Ülkemizde BVDV seroprevalans1 araştırmalarında; Aydın Yöresinde \%86 (Tan ve ark., 2006), Burdur'da \%76-81.5 (Kale, 2007; Öztürk ve ark., 2012), Konya ve çevresinde $\% 90.63$ (Kayacan ve Yapic1, 2008), Afyonkarahisar'da \%84.6 (Erol ve ark., 2014), Samsun, Sivas, Tokat İllerinde \%20.19 (Yazıcı ve ark., 2007), Muğla ili ve çevresinde \%49.9 (Şişman ve Akkan, 2008) seropozitiflik rapor edilmiştir. 
$\mathrm{Bu}$ çalışmada ise BVDV enfeksiyonu seroprevalans1 \%75.22 oraninda tespit edildi. Bu oran Isparta'ya komşu olan Burdur bölgesindeki seropozitiflik (Kale, 2007; Öztürk ve ark., 2012) değerine yakın iken, Aydın (Tan ve ark., 2006), Konya (Kayacan ve Yapıc1, 2008), Afyonkarahisar (Erol ve ark., 2014) illerinde belirlenen seroprevalanstan düşük, Samsun, Sivas, Tokat (Yazıc1 ve ark., 2007) ve Muğla (Şişman ve Akkan, 2008) illerindeki seroprevalanstan yüksektir. Bu farklııklar; araştırmada kullanılan test yöntemlerinin farklı olmasindan, materyallerin toplandığı işletmelerde PI hayvan varlığının olup olmadığından, bölgelerdeki hayvan hareketlerinin çok veya az olmasından ve hastalığa karşı herhangi bir koruyucu önlem alınıp alınmadığından kaynaklanabilir. Persiste hayvanların sürü içerisinde yaygınlığ1 dünya genelinde \%1-2 oranındadır (Houe, 1999; Wittum ve ark., 2001). Bir sürüde seropozitiflik oranının yüksek olması o sürü içerisinde PI hayvanın varllğının göstergesi sayılmaktadır (Houe, 1999).

Houe ve Meyling (1991) tarafindan Danish sütçü sürülerinde yaptıkları çalışmada, \%1.4 oranında PI hayvan tespit etmişlerdir. Hashemi Tabar ve ark. (2010) tarafindan, İran'da abort yapmıs ineklerden topladıkları serum örneklerinde $\% 1.67$ oranında PI hayvan belirlemişlerdir.

Ülkemizde, Burgu ve ark. (2003) tarafindan Türkiye'nin farklı bölgelerinde bulunan 26 süt sığırcilığ işletmesinde persiste enfeksiyon oranını \%0.61-0.83, Şimşek ve Öztürk (1997) tarafindan Konya'da \%0.7, Bulut ve ark. (2006) tarafindan Konya bölgesinde \%0.1, Ak ve ark. (2002) tarafindan Trakya yöresinde \%3.07, Tan ve ark. (2006) tarafindan Aydın ili ve çevresinde \%4.9 olarak bildirmişlerdir.

Bu çalışmada, 460 tane hayvandan 5 tanesi (\%1.09) persiste enfekte (PI) olarak belirlendi. Çalışmada tespit edilen PI oranı dünya genelinde bildirilen oranlarla uyumlu iken (Hashemi Tabar ve ark., 2010; Houe, 1999; Houe ve Meyling, 1991; Wittum ve ark., 2001), ülkemizde belirlenen PI oranları ile farklılı göstermektedir (Ak ve ark., 2002; Burgu ve ark., 2003; Şimşek ve Öztürk 1997, Tan ve ark.
2006). PI oranının ülkemizdeki bazı çalışmalarda düşük olması, araştırma bölgelerinde daha önce yapılan araştırmalarda tespit edilen (Bulut ve ark.,2006; Şimşek ve Öztürk, 1997) PI hayvanların eradike edilmesinden, PI oranın yüksek olması (Ak ve ark., 2002; Tan ve ark. 2006) ise bölgelerde PI enfekte hayvan tespiti ile ilgili araşturmanın az olması ve hastalıkla ilgili yeterli koruma ve kontrol önlemlerinin alınmadığından kaynaklanabilir.

Hastalığı seroprevalansı 1rklara göre değerlendirildiğinde; holştayn 1rk1 sığırlardan alınan 429 adet kan numunesinin 327 (\%76.22) tanesi seropozitif, $102(\% 23.78)$ seronegatif bulundu. Simental ırkı sığırlardan alınan 18 adet kan numunesinin $13(\% 72.22)$ tanesi seropozitif, 5 $(\% 27.78)$ tanesi seronegatif tespit edildi. Montafon 1rkından alınan 13 tane kan numunesinin 6 (\%46.15) tanesi seropozitif, 7 (\%53.85) tanesi seronegatif olarak saptandi. Holştayn, Simental, Montafon 1rkları arasında da $\left(\mathrm{X}^{2}\right)$ testine göre istatiksel önem belirlendi $(p<0.05)$. Şişman ve Akkan (2008) tarafindan yapılan araştırmalarında, 1rk yönünden montafon 1 rk1 ile holştayn, simmental ve melez irklar arasinda istatiksel önemin olduğunu bildirmiştir. Ayııca, İssi ve ark. (2006), BVDV enfeksiyonunda saf ırkların etkene karş1 serum nötralize antikor ürettiklerini, hastalarda çoğunlukla birkaç günde iyileşme olduğunu ve hastalığın subklinik ilerlediğini bildirmişlerdir.

Mockeliuniene ve ark. (2004) tarafindan yapilmış olan bir araştırmada yaş arttıkça seropozitiflik yüzdesinin artığını bildirmişlerdir.

$\mathrm{Bu}$ çalş̧mada, BVDV enfeksiyonunun seroprevalansının yaş aralığına göre dağılımında 6 ay-3 yaş grubu arasında 146 adet hayvandan 74 $(\% 50.68)$ tanesi seropozitif, $72(\% 49.32)$ tanesi seronegatif, 3-6 yaş grubu arasında 207 hayvandan $170(\%$ 82.13) tanesi seropozitif, $37(\% 17.87)$ tanesi seronegatif; 6 yaş ve üzerinde ki grup arasinda ise 107 hayvandan $102(\% 95.33)$ tanesi seropozitif, 5 (\%4.67) tanesi seronegatif olarak belirlendi. Yaş grupları arasında en düşük seropozitiflik yüzdesi 6 ay-3 yaş grubu arasında $\% 50.68$, en yüksek seropozitiflik 6 yaş ve üzeri 
olan grupta \%95.33 olarak tespit edildi. Yaş grupları arasında $(\mathrm{p}<0.05)$ istatiksel önem belirlendi. Ayrıca yaş ile seropozitif ve seronegatiflik arasındaki korrelasyon testine göre yaş arttıkça seronegatiflik azaldığ1 saptandi. Diğer bir ifadeyle, çalışmada yaş arttıkça seropozitiflik yüzdesinin arttığ görülmüş olup bu durum Mockeliuniene ve ark. (2004) tarafindan yapilan araşturma ile uyumludur.

\section{Sonuç}

Çalısmanın bulgularına göre; Isparta İli ve çevresinde sığırcllık işletmelerinde Bovine Viral Diyare Virus (BVDV) Enfeksiyonu için \%75.22 oranında seropozitiflik ve $\% 1.09$ oranında persiste enfekte (PI) hayvan belirlenmiştir. Sonuç olarak; BVDV enfeksiyonunun seropozitiflik ve PI oranı değerlendirildiğinde, enfeksiyonun Isparta İli ve çevresinde yaygın olduğu görülmektedir. Bu nedenle hastalığa karşı gerekli kontrol ve koruma önlemlerinin alınması bölge ve ülke ekonomisi için önem arz etmektedir.

Moennig ve ark. (2005) tarafindan PI hayvanların sürüden çıkarılmasını önermektedirler. Çalışmada, PI hayvan olarak değerlendirilen 5 tane hayvan için işletme sahiplerine, bu hayvanların kesime sevk edilmesi önerilmiştir.

Persiste enfekte hayvanların identifikasyonu ve eliminasyonu, aşlama yoluyla BVDV enfeksiyonuna karşı immünitenin arttırılması, biyogüvenlik tedbirlerin geliştirilmesi ve uygulanmasını içeren 3 ana ilke üzerine kontrol programlarına odaklanılmalıdır (Walz ve ark., 2010).

Türkiye'de BVD hastalığına karşı henüz belli başlı bir koruma kontrol programı uygulamaya konulmamıştır. Piyasada inaktif BVDV aşları mevcut olsa da yeteri kadar uygulama alanı bulamamaktadır.

Dünya üzerinde enfeksiyonun yüksek prevalansa sahip olması, ülke ve dünya hayvancilı̆̆ına ciddi etkileri olması açısından topyekün koruma kontrol programlarının uygulanması gerekmektedir.
Bu çalışmada yüksek seropozitiflik belirlenmiştir. Hastalıktan arî olmayan hayvanların il ve ilçeler aras1 hareketleri hastalı̆̆n yayılmasında etkili olmaktadır. Isparta'ya komşu olan Burdur, Afyonkarahisar, Konya İlleri arasinda hayvan hareketleri çok fazla olmaktadır. Isparta, Burdur, Afyonkarahisar, Konya İllerinde de seroprevalansin yüksek olması bunun kanit olabilir.

Viral etkenler evcil hayvanlarda oluşturdukları enfeksiyon neticesinde tedavi masraflarında artış, verim düşüklüğü ve ölüme bağlı kayıplar sebebiyle ekonomik önem arz etmektedirler (Yıldırım ve Burgu, 2005). Bu yüzden BVDV enfeksiyonu Türkiye'de mücadele edilmesi, koruma ve kontrol programları uygulanması gereken ciddi bir hastaliktır.

\section{Teşekkür}

$\mathrm{Bu}$ çalışma, Burdur Mehmet Akif Ersoy Üniversitesi Bilimsel Araştırma Projeleri Komisyonu tarafindan Yüksek Lisans Tez Projesi olarak desteklenmiştir. (Proje No: 0233-YL-14).

\section{Kaynaklar}

Ak, S., Fırat, İ., Bozkurt, H.H., Gülyaz, V., Ak, K., 2002. The prevalence of bovine viral diarrhoea virus (BVDV) infections in cattle and existence of persistently infected cattle in the Trakya Region. Turkish Journal of Veterinary and Animal Sciences 26, 245-248.

Avc1, O., Yavru, S., 2013. Investigation of Bovine Herpesvirus-1, Bovine Viral Diarrhea Virus and Bovine Herpesvirus-4 in a dairy herd with naturally infected in Konya. Eurasian Journal Veterinary Science 29, 82-86.

Bulut, O., Yavru, S., Yapkıç, O., Kale, M., Avcı, O., Hasırcioğlu, S., 2006. Sütçü sığırların bovine herpesvirus 1 (BHV-1) ve bovine viral diarrhoea virus (BVDV) enfeksiyonları yönünden elisa ile araștıılması. Hayvancllık Araşurma Dergisi 16(2), 18-24.

Burgu, İ., Alkan,F., Özkul, A., Yeşilbağ, K., Karaoğlu, T., Güngör, B., 2003. Türkiye'de süt sığırcllı̆ı işletmelerinde bovine viral diarrhea (BVDV) enfeksiyonunun epidemiyolojisi ve kontrolü. Ankara Üniversitesi Veteriner Fakültesi Dergisi 50, 127-133.

Decaro, N., Mari, V., Lucente, M.S., Sciaretta, R., Moreno, A., Armenise, C., Losurdo, M., Camero, M., Lorusso, E., Cordioli, P., Buonavoglia, C., 
2012. Experimentalinfection of cattle, sheep and pigs with 'Hobi'-like pestivirus. Veterinary Microbiology 155, 165-171.

Duong, $\quad$ M.C., Alenius, S., Huong, L.T.T., Björkman, C., 2008. Prevalence of Neospora caninum and bovine viral diarrhoea virus in dairy cows in Southern Vietnam. Veterinary Journal 175(3), 390394.

Erol, N., Gür, S., Acar, A., 2014. A Serological investigation for Bovine Viral Diarrhea Virus infection in and around Afyonkarahisar province. West Anatolia. Kocatepe Veterinary Journal 7(1), 17-21.

Greiser-Wilke, I., Grummer, B., Moennig, V., 2003. Bovine viral diarrhoea eradication and control programmesin Europe. Biologicals journal 31, 113118.

Grooms, D.L., 2004. Reproductive consequences of infection with bovine viral diarrhea virus. Veterinary Clinics of North America Food Animal Practice 20, 519.

Hashemi Tabar, G.R., Haghparast, A., Naseri, Z., 2010. Prevalence of bovine viral diarrhea virus antibodies and antigen among the aborted dairy cows in industrial dairy cattle herds in Mashhad Area-Iran. World Applied Sciences Journal 8(5), 635-640. 10

Houe, H., 1999. Epidemiological features and economical importance of bovine virus diarrhoea virus(BVDV) infections. Veterinary Microbiology 64(23), 89-107.

Houe, H., Meyling, A., 1991. Prevalence of Bovine Virus Diarrhoea (BVD) in 19 Danish Dairy Herds and Estimation of Incidence of Infection in Early Pregnancy. Preventive Veterinary Medicine11, 9-16.

Houe, H., Lindberg, A., Moennig, V., 2006. Test strategies in bovine viral diarrhea virus control and eradication campaigns in Europe. J Vet Diagn Invest 18, 427-436.

İssi, M., Gülaçtı, İ., Kızıl, Ö., Karapınar, T., Bulut, H., Gül, Y., 2006. Kliniğimizde gözlemlenen reverse transkriptaz-polimeraz zincir reaksiyonu (RT-PCR) ile doğrulanan mukoza hastalı̆̆1 olguları. Firat Üniversitesi Sağl1k Bilimleri Dergisi 20(3), 253-258.

Kale, M., 2007. Sığırlarda Bovine Viral Diarrhea Virus (BVDV) Enfeksiyonunun Fertilite ile İlişkisinin Araştırılması. TÜBİTAK Projesi, Proje No: 1060366 Burdur,. s. 1-116.

Kayacan, G., Yapıc1, O., 2008. Konya İli ve çevresinde bulunan süt sığırcllı̆̆ işletmelerinde ki hayvanlara ait kan ve süt serumlarında Bovine Viral Diarrhea (BVDV)'una karşı oluşan antikorların ELİSA ile araştırılması. Yüksek Lisans Tezi, Selçuk Üniversitesi Sağlık Bilimleri Enstitüsü, Konya.

Kuta, A., Polak. M.P., Larska, M., Zumudzinski, J.F., 2013. Monitoring of Bovine Viral DiarrhoeaVirus (BVDV) infection in Polish dairy herdsusing bulk tank milksamples. Bulletin of the Veterinary Institute in Pulawy 57, 149-156.

McGowan, M., Kirkland, P., Richards, S., Littlejohns, I., 1993. Increased reproductive losses in cattle infected with bovine pestivirus around the time of insemination. Veteriner Record 133, 39-43.

Mockeliuniene, V., Salomskas, A., Mockeliunas, R., Petkevicius, S., 2004. Prevalence and Epidemiological Features Of Bovine Viral Diarrhoea Virus Infection in Lithuania. Veterinary Microbiolgy 99, 51-57.

Moennig, V., Houe, H., Lindberg, A., 2005. BVD control in Europe: current status and perspectives. Animal Health Research Reviews 6, 63-74.

Öztürk, D., Kale, M., Pehlivanoğlu, F., Hasırcioğlu, S., Türütoğlu, H., 2012. Evaluation for Some Bacterial and Viral Abortions of Dairy Cattle Farms in Burdur District of Turkey. Kafkas Üniversitesi Veteriner Fakültesi Dergisi 18(2), 255-258.

Radositist, O.M., Gay, C.C., Hinchcliff, K.W., Constable, P.D., 2006. Veterinary Medicine,A Textbook of the diseases of cattle, horses, sheep, pigs and goats.10th edition. Philadelphia, Saunders ltd, pp. 1248-1277.

Ridpath, J.F., Fulton, R.W., Kirkland, P.D., Neill, J.D., 2010. Prevalence and antigenic differences observed between Bovine Viral diarrhea virus subgenotypes isolated from cattle in Australia and feedlots in the southwestern United States. The Journal of Veterinary Diagnostic Investigation 22, 184-191.

Robert, A., Beaudeau, F., Seegers, H., Joly, A., Philipot, J., 2004. Large scale assessment of the effect associated with bovine viral diarrhoea virus infection on fertility of dairy cows in 6149 dairy herds in Brittany (Western France). Theriogenology 61, 117-127.

Rodning, S.P., Marley, M.S., Zhang, Y., Eason, A.B., Nunley, C.L., Walz, P.H., Riddell, K.P., Galik, P.K., Brodersen, B.W., Givens, M.D., 2010. Comparison of three commercial vaccines for preventing persistent infection with bovine viral diarrhea virus. Theriogenology 73(8), 1154-11636.

Şimşek, A., Öztürk, F., 1997. Klinik olarak sağlıklı sığır sürülerinde persiste bovine viral diarrhea virus enfeksiyonlanının araştırılması ve epizootiyolojik önemi. Veteriner Bilimleri Dergisi 13(2), 113-119. 
Şişman, H., Akkan, H.A., 2008. Muğla İli ve çevresinde sığırcılık işletmelerinde Bovine Viral Diyare (BVDV) enfeksiyonunun serolojik olarak araştırilması. Yüksek Lisans Tezi, Yüzüncü Yıl Sağlık Bilimleri Enstitüsü, Van

Tan, M.T., Karaoğlu, T., Erol, N., Yıldırım, Y., 2006. Serological and virological investigations of bovine viral diarrhoea virus (BVDV) infection in dairy cattle herds in Aydin province. Turkish Journal of Veterinary and Animal Sciences 30, 299-304.

Walz, P.H., Grooms, D.L., Passler, T., Ridpath, J.F., Tremblay, R., Step, D.L., Callan, R.J., Givens, M.D., 2010. Control of Bovine Viral Diarrhea Virus in Ruminants. Journal of Veterinary Internal Medicine 24, 476-486.

Wittum, T.E., Grotelueschen, D.M., Brock, K.V., Kvasnicka, W.G., Floyd, J.G., Kelling, C.L., Odde,
K.G., 2001. Persistent bovine viral diarrhoea virus infection in US beef herds. Preventive Veterinary Medicine 49, 83-94.

Xue, W., Mattick, D., Smith, L., Maxwell, J., 2009. Fetal protection against bovine viral diarrhea virus types 1 and 2 afterthe use of a modified-live virus vaccine. The Canadian Journal of Veterinary Research 73, 292297.

Yazıc1, Z., Okur, Gümüşova, S., Albayrak, H., 2007. Serological profile of some viral infections in unvaccinated cattle in Turkey. Medycyna Weterinaryjna 63(2), 187-189.

Yıldırım, Y., Burgu, İ., 2005. Kuzeydoğu Anadolu bölgesindeki sığırlarda mavi dil (BT), IBR, PI-3, EBL ve BVD enfeksiyonlarının seroprevalansı. Ankara Üniversitesi Veteriner Fakültesi Dergisi 52, 113-117. 